\title{
On the Effective Shear Modulus of Composite Honeycomb Sandwich Panels
}

\author{
Lamine Rebhi ${ }^{1)}$ \\ Mirko Dinulović ${ }^{2)}$ \\ Predrag Andric ${ }^{3)}$ \\ Marjan Dodić ${ }^{1)}$ \\ Branimir Krstic ${ }^{1)}$
}

\begin{abstract}
In the presented paper the effective shear modulus of composite plates with honeycomb core is determined. This elastic coefficient represents one very important property, especially in constructions subjected to torsion and combined bending torsion. The structures investigated in this research consisted of top and bottom plates (of different types of carbon fibers, T300, AS4 in epoxy matrix) and honeycomb core (HexWeb engineered core). Starting from classical lamination theory, the effective shear modulus of top and bottom plates was determined for each ply in the stack up sequence. These plies were "lumped" into a single composite layer for different fiber orientations and plies thicknesses. Elastic coefficients for the HexWeb engineered core were obtained using Master and Evans relations for the equivalent properties of honeycomb cores. To verify this approach, finite element method was used to determine the displacement, stress and strain field on composite plates with honeycomb core. Two types of models were compared: the initial model where all the material components, plates and the core were modeled with their intrinsic properties and "lumped" model with calculated effective elastic coefficients. It was found that the method of effective shear modulus calculation can successfully be used in situations where top and bottom plates are symmetric or quasi isotropic in general.
\end{abstract}

Key words: composite materials, honeycomb structure, panel, plates, torsion, bending, sliding module, finite element method.

\section{Introduction}

$\mathrm{S}_{\mathrm{s}}^{\mathrm{N}}$ ANDWICH composites are widely used in aerospace structural design, mainly for their ability to substantially decrease weight while maintaining the mechanical performance. It has been known for a long period of time, that separating two stiff materials (facings or stress skins) with a lightweight material (core) increases the structure's stiffness and strength.

The faces carry the tensile and compressive stresses in the sandwich. Faces can be manufactured from metallic material (such as Al 3003, Al 5052, Al 5056), however polymer matrix composites are being used more and more as face materials. Composites can be tailored to fulfill a range of demands like anisotropic mechanical properties, freedom of design, excellent surface finish, etc. Faces also carry local pressure. When the local pressure is high, the faces should be dimensioned for the shear forces connected to it.

The core's function is to support the thin skins so they do not buckle (deform) inwardly or outwardly, to keep them in relative position to each other and to carry shear stresses. In order to accomplish this, the core must have several important characteristics. It has to be stiff enough to keep the distance between the faces constant. It also must be so rigid in shear that the faces do not slide over each other. The shear rigidity forces the faces to cooperate with each other. If the core is weak in shear, the faces do not cooperate and the sandwich will lose its stiffness. It is the sandwich structure as a whole that gives the positive effects. However, the core has to fulfill the most complex demands. Strength in different directions and low density are not the only properties the core must have. Often there are special demands for buckling, insulation, absorption of moisture, aging resistance, etc. The core can be made of a variety of materials, such as wood, aluminum (Al 3003, Al 5052, Al 5056), variety of foams (Corecell M Foam) and polymer matrix composite materials (Fig.1).

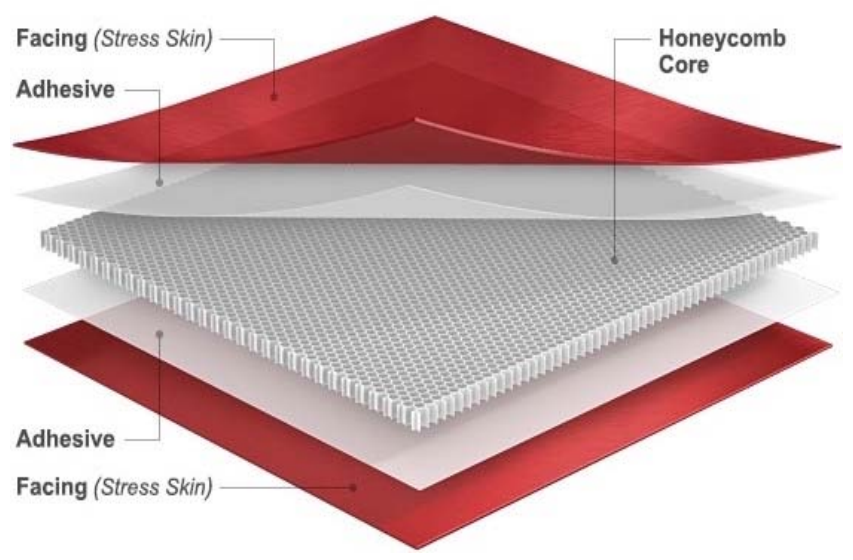

Figure 1. Composite panel with honeycomb core construction

\footnotetext{
1) University of Defence, Military Academy, Generala Pavla Jurišića Šturma 33, 11000 Belgrade, SERBIA

2) University of Belgrade, Faculty of Mechanical Engineering, Kraljice Marije 16, 11020 Belgrade 35, SERBIA

3) École Polytechnique Fédérale de Lausanne, Institute of Mechanical Engineering, Lausanne, SWITZERLAND

Correspondence to: Lamine Rebhi; e-mail: rebhi.lamine@gmail.com
} 
To keep the faces and the core cooperating with each other, the adhesive between the faces and the core must be able to transfer the shear forces between them. The adhesive must be able to carry shear and tensile stresses. It is hard to specify the demands on the joints.

It is of a great importance to predict, during the design phase, the properties of above mentioned construction. This usually means accurate estimation of all elastic coefficients $\left(E_{i j}, G_{i j}, v_{i j}, i, j=x, y\right.$, Young's modulii, Shear modulii and Poisson's ratios) based on sandwich panel geometry (core cell geometry, cell wall thickness, facings thicknesses, etc.) and panel constituents material properties.

In the present work, the shear modulii (in-plane $G_{x y}$ and out-of-plane, $G_{x z}$ and $G_{z y}$ ) of the panel with composite hexagonal core and composite faces are investigated and the model for these properties calculation is proposed.

\section{Nomex production}

First, the manufacturing process of the core will be analyzed. The emphasis will be given to the composite material cores. Nomex is a trademark of non-metallic paper (honeycomb core basic building block) material, which is well known for its excellent mechanical and other properties relevant for aerospace applications.

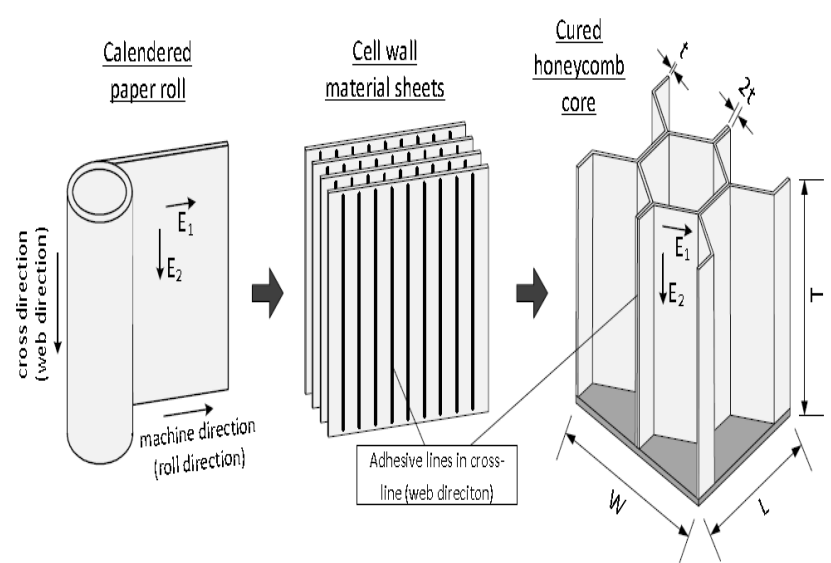

Figure 2. Honeycomb (hexagonal) core production process scheme

In general, the paper is a composite that consists of two forms of polymers, the fibrids (small fibrous binder particles) and the floc (short fibers). These two components are mixed in a water-based slurry and machined in a continuous sheet. Subsequent high-temperature calendering leads to a dense and mechanically strong paper material (Fig.2).

During this manufacturing process, the longer floc fibers may align themselves in direction of the paper coming off the machine, which leads to orthotropic mechanical structure, or the fibers may randomly distribute themselves in the paper resulting in a $2 \mathrm{D}$ random composite structure (it is assumed that the paper is manufactured to be relatively thin, hence 2D structure results). The latter case will be considered in this paper.

Further processing of this paper material to form hexagonal cells is commonly carried out using the adhesive bonding method, meaning that the bonded portion of two adjacent paper sheets is held together by adhesive. This method inevitably leads to double the wall thickness of the bonded cell walls if compared to the unbonded "free" cell walls (Fig.3).

After the paper sheets are bonded and shaped to hexagonal cells, the resulting honeycomb block is dipped in liquid resin (usually phenolic based) and subsequently oven cured. This dipping-curing process is repeated until the desired density of the core is achieved. The resulting resin coating of the paper leads to a layered material with an orthotropic or 2D anisotropic ductile center layer (core paper) and two isotropic very brittle outer layers (resin layers).

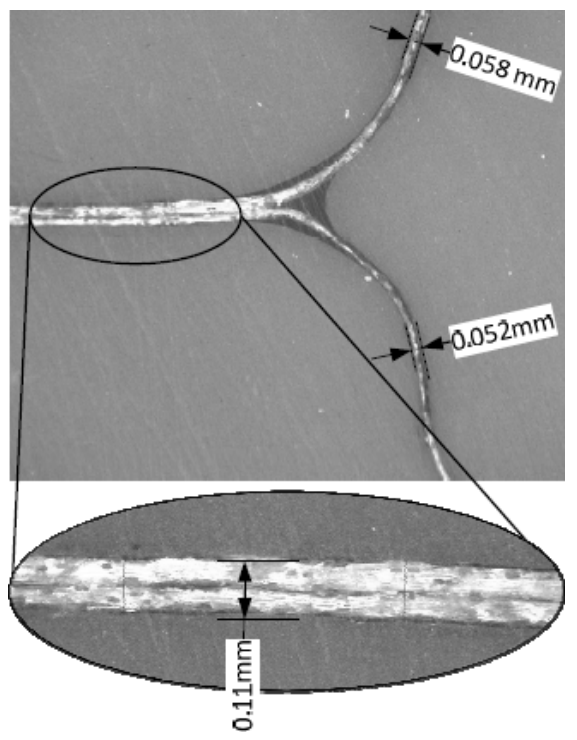

Figure 3. Double wall thickness

\section{Analytical model of shear modulus for the honeycomb core}

In order to relate stress and strain in the structure the constituent material properties have to be known and elastic coefficient in the stiffness matrix have to be calculated. For the structures investigated in this paper the determination of the necessary elastic coefficients is very complex due to complex geometry of the panel, a furthermore complex structure of the constituent materials i.e. core and facings. The analyst relies on the manufacturer data or has to perform tests if the all required values of the elastic coefficients are not supplied. Secondly, numerical studies can be performed, requiring large and cumbersome finite element models if the equivalent model approach is not taken. This method consists of lumping several composite layers into a single (lumped) layer with the same characteristics rendering the same stress strain (although averaged) and displacement fields for the same boundary conditions. It is true that this approach still requires numerical modeling of the structure, however, the models based on equivalent material properties are much smaller in size (less DOF's), hence requiring less confrontational resources, computing time and yielding stressstrain and displacement fields much faster compared to detailed (micro mechanics models). This is the reason why the validation and determination of the equivalent material properties (especially when the composite panels with honeycomb core are in question). The literature survey on the subject matter has revealed that the development of equivalent composite models is in the focus of many researchers. For example, Master and Evans model for equivalent Young's modulii in fiber and cross fiber directions, Ashby's model for equivalent in-plane shear modulus are only few of several existing models. However, all this models assume that the starting material is isotropic. For example, in Master and Evans model one of the required input variables is $E_{f}$, which represents the Young's modulus of the paper. This is directly applicable for honeycomb cores where the basic building material is isotropic (for example: hexagonal aluminum 
cores), in cases where the cores are manufactured from composite materials (section 2), the equivalent properties of the building core material have to be determined first before using one of the already established and proven material equivalent material properties.

\section{Honeycomb core with $2 D$ random fibers}

If the paper material is manufactured in such a way that the resulting material is anisotropic and consists of polymer matrix and randomly distributed fibers (in a 2D plane), the effective Young's modulus of such a structure can be determined based on Christensen and Waals model [1]

Christensen and Waals examined the behavior of a composite system with a three-dimensional random fiber orientation. Both fiber orientation and fiber-matrix interaction effects were considered. For low fiber volume fractions, the modulus of the $3 \mathrm{D}$ composite was estimated to be:

$$
E_{2 D}=\frac{V_{f}}{6} \cdot E_{f}+\left[1+\left(1+v_{m}\right) \cdot V_{f}\right] \cdot E_{m}
$$

Where $V_{f}$ is the fiber volume fraction in the composite, $v_{m}$ is the matrix Poisson's ratio $E_{f}$ an $E_{m}$ are the Young's modulii of the fiber and matrix phase respectively. Since it can be considered that the core composite (paper) is isotropic (fibers are evenly distributed), the basic relation between Young's modulus $(E)$, Shear modulus $(G)$ and Poisson's ratio holds. Manera [2] proposed approximate equations to predict the elastic properties of randomly oriented short fiber composites. Using this approach, it can be shown that for this type of composites (thin plates, with randomly distributed short fibers) Poisson's ratio is $v=1 / 3$. Using relation:

$$
G_{2 D}=\frac{E_{2 D}}{2 \cdot\left(1+2 v_{f}\right)}
$$

In-plane shear modulus for the paper of the composite honeycomb structure can be calculated.

As described in previous section, the paper core is dipped in resin (several times until the desired density of the paper used for honeycomb structure is achieved).

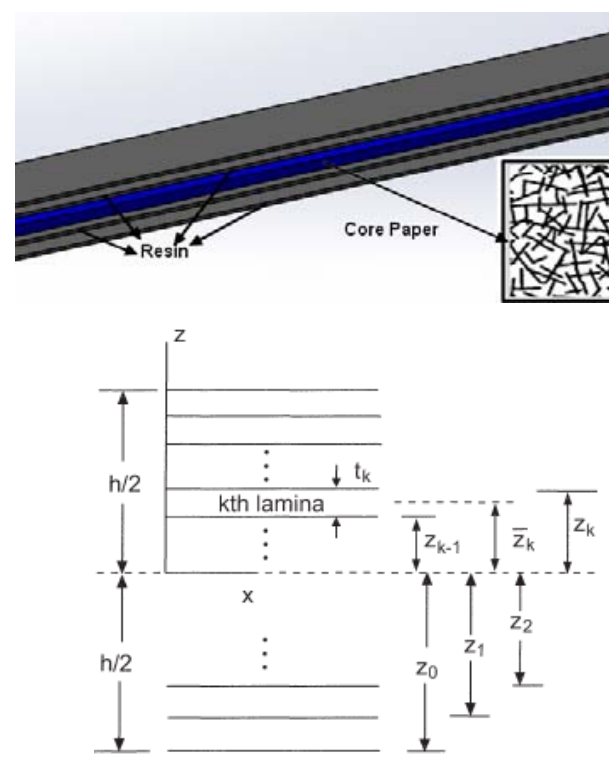

Figure 4. Core paper with added isotropic resin layers

This process adds rigidity to the paper and equations (1) and (2) have to be modified to account for this effect. Resin properties (Modulus of elasticity, Shear Modulus) are known and classical lamination theory (CLT) can be applied in this case. Also resin itself is considered to be isotropic. Theretofore, it follows that using CLT, stresses in each core paper layer can be expressed in the following form:

$$
\left\{\begin{array}{c}
\sigma_{x} \\
\sigma_{y} \\
\tau_{x y}
\end{array}\right\}=\left[\begin{array}{ccc}
Q_{1} & Q_{2} & 0 \\
Q_{2} & Q_{1} & 0 \\
0 & 0 & Q_{6}
\end{array}\right]\left\{\begin{array}{c}
\varepsilon_{x} \\
\varepsilon_{y} \\
\gamma_{x y}
\end{array}\right\}
$$

Where,

$$
Q_{1}=\frac{E_{i}}{1-v_{i}^{2}}, Q_{2}=\frac{E_{i} \cdot v_{i}}{1-v_{i}^{2}}, Q_{6}=G_{i}
$$

In equations (4), index ' $i$ ' denotes the elastic coefficient for the corresponding layer, for example if the central mid-layer is in question, the value of $E_{i}$ is calculated according to equation (1) and all other layers (resin) assume their intrinsic values of $E$. Same applies to shear modulus and Poisson ratio in equations (4).

Expressing relation (3) in terms of in-plane resultant forces one can obtain:

$$
\left\{\begin{array}{c}
N_{x} \\
N_{y} \\
N_{x y}
\end{array}\right\}=\int_{-t / 2}^{t / 2}\left\{\begin{array}{l}
\sigma_{x} \\
\sigma_{y} \\
\tau_{x y}
\end{array}\right\} \cdot d z
$$

Where $\mathrm{t}$ denotes thickness of the layer (Fig.4)

For the whole lay-up it follows:

$$
\left\{\begin{array}{l}
N_{x} \\
N_{y} \\
N_{x y}
\end{array}\right\}=\sum_{i=1}^{n} \int_{-t / 2}^{t / 2}\left\{\begin{array}{l}
\sigma_{x} \\
\sigma_{y} \\
\tau_{x y}
\end{array}\right\} \cdot d z
$$

In the previous relation $\mathrm{n}$ denotes the total number of layers (core paper and resin layers), therefore it can be written:

$$
\left\{\begin{array}{l}
N_{x} \\
N_{y} \\
N_{x y}
\end{array}\right\}=\sum_{i=1}^{n} \int_{z k-1}^{z_{k}}[Q]_{k} \cdot\{\varepsilon\} d z
$$

Or rewriting the previous relation,

$$
\{N\}=[A] \cdot\{\varepsilon\}
$$

Matrix A is stiffness matrix and all coefficients $A_{i j}(i=1,2,6$ $j=1,2,6$ ) can easily be calculated once all the properties of all the layers are known.

$$
A_{i j}=\int_{-t / 2}^{t / 2} Q_{i j}^{(k)} \cdot d z=\sum_{k=1}^{n} Q_{i j}^{(k)} \cdot\left(z_{k}-z_{k-1}\right)
$$

Since the lay-up in this case is considered to be symmetric, it can be concluded that the effective shear modulus for this structure can be expressed as:

$$
G_{x y}^{e f f}=\frac{A_{66}}{h}
$$

In equation (10) $\mathrm{h}$ denotes total thickness of the laminate (core paper and resin layers).

\section{Honeycomb core with orthotropic material}

During certain manufacturing process, the floc fibers can be aligned in the direction of the paper coming off the machine. This leads to orthotropic mechanical properties of the paper. 


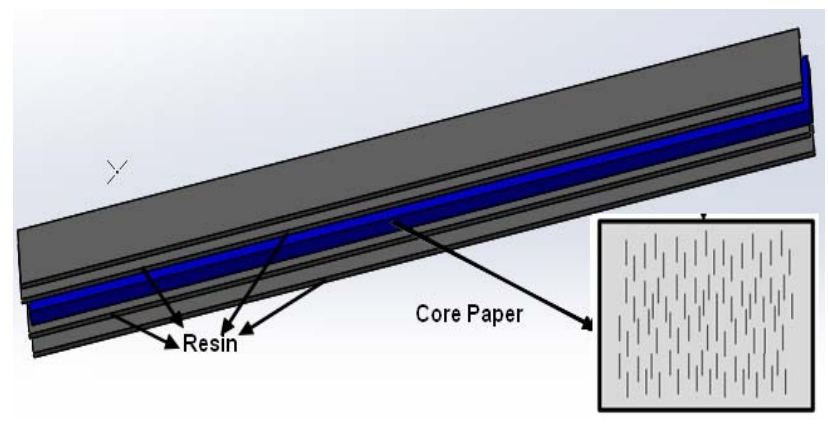

Figure 5. Core paper (orthotropic) with added isotropic resin layers

For this type of composite equation (3) assumes the following form:

$$
\left\{\begin{array}{l}
\sigma_{x} \\
\sigma_{y} \\
\tau_{x y}
\end{array}\right\}=\left[\begin{array}{ccc}
Q_{11} & Q_{12} & 0 \\
Q_{21} & Q_{22} & 0 \\
0 & 0 & Q_{66}
\end{array}\right]\left\{\begin{array}{c}
\varepsilon_{x} \\
\varepsilon_{y} \\
\gamma_{x y}
\end{array}\right\}
$$

Where $Q_{i j}$ are given in the following form:

$$
\begin{aligned}
& Q_{11}=\frac{E_{i 1}}{1-v_{i 12} \cdot v_{i 21}}, Q_{12}=Q_{21}=\frac{E_{i 2} \cdot v_{i 21}}{1-v_{i 12} \cdot v_{i 21}}, \\
& Q_{22}=\frac{E_{i 2}}{1-v_{i 12} \cdot v_{i 21}}, Q_{66}=G_{i x y}
\end{aligned}
$$

Coefficients $Q_{i j}$ for the mid-layer (core paper) can be calculated by using standard rule of mixture theory (ROM). Using rule of mixtures theory shear modulus $G_{x y}$ is obtained using known relation:

$$
G_{12}=\frac{G_{f} \cdot G_{m}}{V_{f} \cdot G_{m}+V_{m} \cdot G_{f}}
$$

Where $\mathrm{V}_{\mathrm{f}}$ and $\mathrm{V}_{\mathrm{m}}$ are fiber and matrix volume fractions, and $G_{f}$ and $G_{m}$ are shear modulii of the fiber and matrix phases. This relation, as experiments have shown, tends to underestimate the value of $G_{12}$, and semi-experimental HalpinTsai theory is used instead. According to this theory the $G_{12}$ modulus can be obtained using the following relation:

$$
G_{12}=\frac{\left(V_{f}+\eta_{12} \cdot V_{m}\right) \cdot G_{f} \cdot G_{m}}{\left(G_{m} V_{f}+\eta_{22} \cdot V_{m} G_{f}\right)}
$$

Correction coefficients $v_{12}$ and $v_{22}$ depend on the fiber type used in the core paper and are given for typical fibers used in honeycomb structure production.

$$
\begin{array}{lll}
\multicolumn{1}{c}{v_{12}} & \multicolumn{2}{c}{v_{22}} \\
\text { Carbon } & 0.500 & 0.400 \\
\text { Glass } & 0.516 & 0.316 \\
\text { Aramid } & 0.516 & 0.400
\end{array}
$$

Once elastic coefficients (equation 14) are computed, effective shear modulus for this type of composite (core paper with resin layers) is calculated using equation (10).

\section{Effective in-plane and out-of-plane shear moduli of hexagonal honeycomb cores}

Many authors have developed theoretical approaches for obtaining the equivalent material properties of honeycomb cores [3]. The nine core material properties are: two in-plane Young's moduli $E_{x}, E_{y}$, the out-of-plane Young's modulus $E_{z}$, in-plane shear modulus $\mathrm{G}_{\mathrm{xy}}$, out-of-plane shear moduli $G_{x z}$, $G_{y z}$, and three Poisson ratios $\mathrm{n}_{\mathrm{xy}}, n_{x z}, n_{y z}$. Using a sensitivity analysis, Schwingshackl et al. [3] reported the major influence of the out-of-plane shear moduli $G_{x z}, G_{y z}$ on displacement, stress and strain fields of the honeycomb core type thin plates. One of the analytical approaches mentioned in this work [3] was developed by Gibson and Ashby [4]. They described the honeycomb core material as a cellular solid made up of an interconnected network of solid structures which form the edges and the faces of the cells. These formulas were later slightly modified by Zhang and Ashby [5] to include double thickness walls for the out-of-plane values, $E_{z}, G_{x z}$, and $G_{y z}$.

The honeycomb cell geometry is presented in the following figure (Fig.6) where 1 and $\mathrm{h}$ indicates the length of the hexagon face; $b$ indicates the height; $t$ indicates the thickness of the face; $\theta$ indicates the semi-angle between two faces.

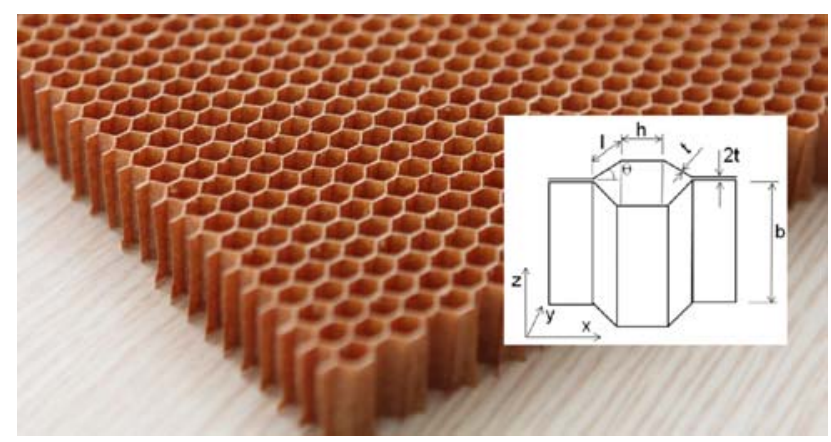

Figure 6. Hexagonal honeycomb core and cell geometry

The equations (15) - (18) represent the equivalent material out-of-plane shear moduli according to [5], and are depicted in the following figure (Fig.7).

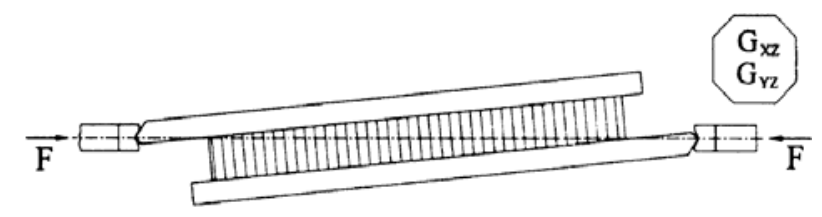

Figure 7. Hexagonal honeycomb core out-of-plane shear moduli $\left(G_{x z}\right.$ and $G_{y z}$

$$
\begin{gathered}
G_{y z}=\frac{\cos \theta}{h / l+\sin \theta} \cdot\left(\frac{t}{l}\right) \cdot G_{x y}^{e f f} \\
G_{x z}^{\text {lower }}=\frac{h / l+\sin \theta}{(1+2 h / l) \cdot \cos \theta} \cdot\left(\frac{t}{l}\right) \cdot G_{x y}^{e f f} \\
G_{x z}^{\text {upper }}=\frac{1}{2} \cdot \frac{h / l+2 \cdot \sin ^{2} \theta}{(h / l+\sin \theta) \cos \theta} \cdot\left(\frac{t}{l}\right) \cdot G_{x y}^{\text {eff }} \\
G_{x z}=G_{x z}^{\text {upper }}+\frac{0.787}{b / l} \cdot\left(G_{x z}^{\text {upper }}-G_{x z}^{\text {lower }}\right) \cdot G_{x y}^{\text {eff }}
\end{gathered}
$$

The in-plane shear modulus is presented in the following figure (Fig.8).

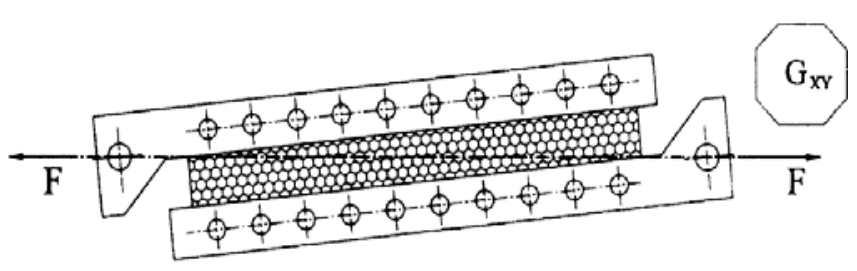

Figure 8. Hexagonal honeycomb core in-plane shear modulus $\left(G_{x y}\right)$

The equivalent in-plane shear modulus for the honeycomb composite core may be expressed by the following equation (19).

$$
G_{x y}=0.2910 \cdot \frac{E_{f} \cdot t}{a}
$$




\section{Numerical model}

In order to verify the validity of the proposed model for shear material properties of composite honeycomb panel, numerical approach using finite elements approach was used. Two FEA models were constructed. The first was mezo-scale model, where complete structure (composite panel with honeycomb core) was modeled using plate finite elements (based on Kirchoff's thin plate theory). In this model each honeycomb cell (Fig.9) was modeled using plate elements according to geometry which corresponds to geometry of HexWeb engineered core, with HRH 10 Nomex, with cell size $h=13[\mathrm{~mm}]$. Dimensions of the analyzed model were $250 \mathrm{~mm}$ x $100 \mathrm{~mm}$ x $25 \mathrm{~mm}$. The plate was clamped at one end, where all translations and rotations were prevented. Displacement was measured at the top plate, free end semi-span. The software used was ANSYS.

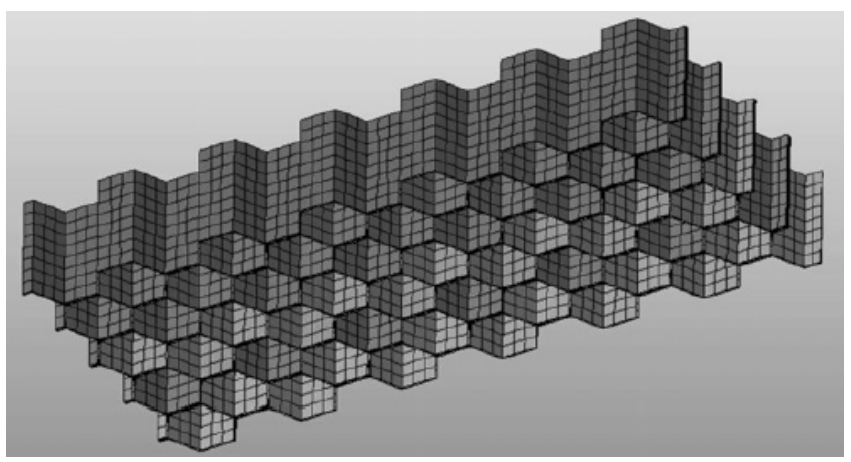

Figure 9. Hexagonal honeycomb core Finite element model

Facings (stress skins, Fig.10) were thin plates, $1 \mathrm{~mm}$ thick made of carbon T-300. Composite lay-up for the facings (lower and upper) was $\left[0^{\circ} / 45^{\circ} /-45^{\circ} / 90^{\circ}\right]$.

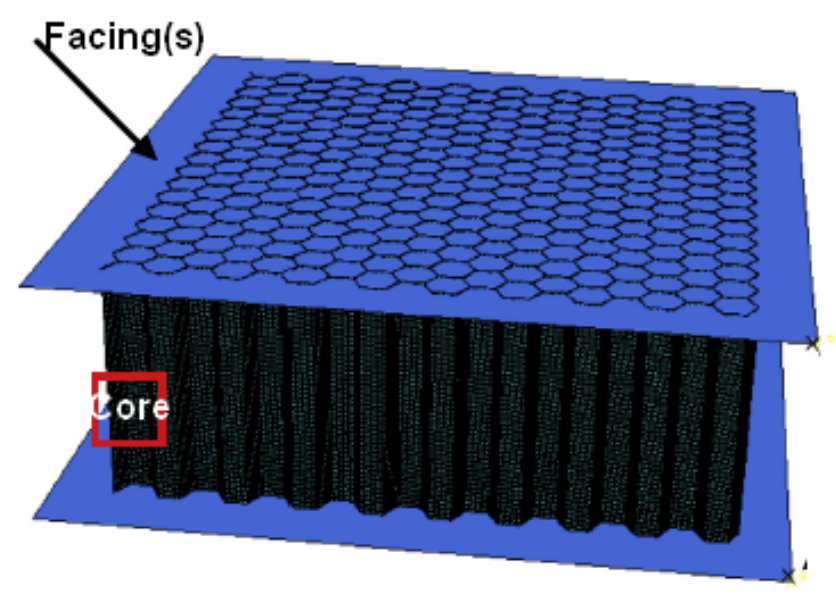

Figure 10. Hexagonal honeycomb core with facings and refined core mesh finite element model

In the second verification finite element model (model 2), the core was modeled using solid elements, where material properties (elastic coefficients in stiffness matrix) were determined using the equivalent material approach, as described in section 3 .

Displacement field was calculated for both models and the results were compared. Boundary conditions under which displacements of the plate tip were determined were the same in both cases. The plate was clamped at one end (all degrees of freedom of end nodes for both translation and rotation are set to zero), whereas the loading moment was applied at the plate's free end. These boundary conditions applied, enforced honeycomb core and facings twist, where shear moduli of the complete structure have an important role and great influence on the complete structure displacement.

The results are shown in the following figure (Fig.11)

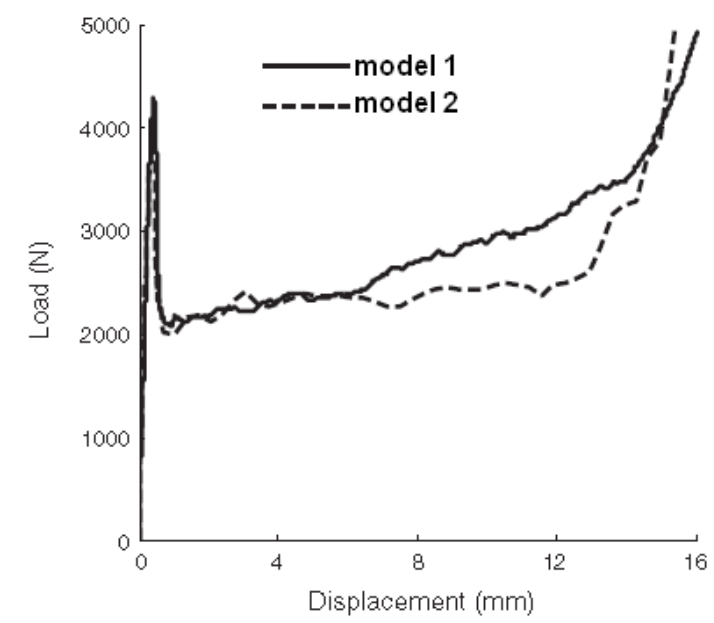

Figure 11. Displacement of plate tip as a function of applied load

\section{Conclusion}

In the present paper Shear properties of the honeycomb plate were investigated. Approach based on the material equivalent model was proposed for the honeycomb cores made of different types of composites. In general, due to complex geometry of hexagonal composite cores, prediction of the elastic coefficients for these types of structures is relatively complicated. One of the approaches is to use numerical approach starting from constituent material properties and creating honeycomb true scale model in order to determine stress-strain and displacement fields. As experiments have confirmed, this approach renders correct results, however these (true scale) models require quite a long development time (each honeycomb cell is modeled independently with large number of elements and hence large number of degrees of freedom), furthermore, in order to solve and obtain desired fields large computing power and time is necessary. Many researchers have focused on finding methodology to find equivalent material models for different types of plates with honeycomb cores with different cell geometries, sizes and constituent materials.

In this paper, Shear moduli (in-plane and out-of-plane) for the hexagon honeycomb core made of different types of composite materials (with aligned and randomly distributed fibers) were investigated. The equivalent material model was presented. To verify equivalent material model validity, the numerical approach was deployed, by creating two different types of models. The true scale model and 'lumped' model were the core material of the honeycomb that was defined using equivalent material properties. Displacement field was calculated for both models and the results were compared. It was found that in the linear region both models yield the same results. Since the computing time for the lumped model is significantly lower its application is recommended. In nonlinear region the equivalent material model yields lower results when compared to the true-scale model which is probably due to very complex core crushing mechanism, and if the results are required in this region the true-scale model has to be developed.

\section{References}

[1] CHRISTENSEN,R.M., WAALS,F.M.: Effective Stiffness of Randomly Oriented Fiber Composites, Journal of Composite Materials, 1972, Vol.6, pp.518-532. 
[2] MANERA,M.: Elastic properties of randomly oriented short fiberglass composites, Journal of Composite Materials, 1977, Vol.11, pp. 235-247

[3] SCHWINGSHACKL,C.W., AGLIETTI,G.S., CUNNINGHAM,P.R.: Determination of honeycomb material properties, Journal of Aerospace Engineering, 2006, 19, pp.177-183.
[4] GIBSON,J., ASHBY,F.: Cellular Solids: Structure and Properties. Cambridge University Press, 2001

[5] ZHANG,J., ASHBY,M.: The out-of-plane properties of honeycombs, International Journal of Mechanical Sciences, 1992, 34, pp.475-489.

\title{
Efektivni modul klizanja kompozitnih panela sa saćastim ispunom
}

\begin{abstract}
U radu je određen efektivni modul klizanja kompozitnog panela sa saćastom ispunom. Ovaj elastični koeficijent predstavlja veoma važnu karakteristiku kompozitnih panela, naročito kod kompozitnih konstrukcija koje su izložene uvijanju kao i kombinovanom uvijanju sa savijanjem. Analizirane strukture u ovom radu sastoje se od gornje i donje kompozitne ploče (različitih tipova karbonskih vlakana, T300, AS4 u epoksidnoj matrici) kao i saćaste ispune (HexWeb EC engineered core). Polazeći od klasične teorije lamine, efektivni modul elastičnosti klizanja je određen za svaki sloj u kompozitnoj ploči. Ovi slojevi su spojeni u jedinstveni kompozitni sloj za različita usmerenja vlakana kao i debljine lamina. Elastični koeficijenti saćaste ispune HexWeb središnjeg sloja kompozitnog panela su izračunati koristeći teoriju Master Evans u cilju dobijanja ekvivalentnih vrednosti. Za proveru predloženog pristupa korišćen je metod konačnih elemenata, u cilju dobijanja polja pomeranja, deformacija i napona u kompozitnim pločama i saćastoj ispuni. Dva tipa numeričkih modela su upoređena: početni model, pri čemu su svi slojevi ploče modelirani sa svojim karakteristikama i drugi model kod kojeg su spojeni u jednu celinu sa svojim ekvivalentnim karakteristikama. Zaključeno je da se ekvivalentni metod određivanja modula klizanja kompozitnih panela sa saćastim ispunama može efikasno primeniti u slučajevima kada su gornja i donja kompozitna ploča simetričnog slaganja ili uopšte kvaziizotropna.
\end{abstract}

Ključne reči: kompozitni materijali, saćasta struktura, panel, ploča, uvijanje, savijanje, modul klizanja, metoda konačnih elemenata.

\section{Эффективный модуль сдвига композитных сэндвич-панелей со сотовой структурой}

\begin{abstract}
В настоящей работе определён эффективный модуль сдвига композитных сэндвич-панелей со сотовой структурой. Этот коэффициент упругости представляет одно очень важное свойство композитных панелей, особенно в композитных конструкциях, подвергаемых скручиванию, а в том числе и комбинированному скручиванию с изгибом. Структуры, исследованные в этой работе, состояли из верхних и нижних композитных панелей (различных типов углеродных волокон, T300, AS4 в эпоксидной матрице) и сотовой структуры (НехWeb EC - инженерии ядра). Начиная от классической теории ламинирования, эффективный модуль упругосити сдвига верхних и нижних панелей определяли для каждого слоя в композитной панели. Эти слои были соединённые в единый композитный слой для разных направлений волокон и толщины слоёв ламинирования.Коэффициенты упругости для сотовой структуры НехWeb сконструированного композитного ядра были вычислены с использованием теории Master и Evans соотношения для эквивалентных значений сотовых ядер. Чтобы проверить этот предложеный подход использован метод конечных элементов для того чтобы получить и определить поля смещения, деформаций и напряжения в композитных панелях со сотовой структурой. Сравнивались два типа численных моделей: начальная модель, в которой все материальные слои в компонентах - плита и ядро были смоделированы с присущими им свойствами и вторая соединённая в одно целое модель с расчётными эффективными коэффициентами упругости. Было установлено, что эффективный метод расчёта модуля сдвига композитных панелей со сотовой структурой может быть успешно использован в ситуациях, когда верхняя и нижняя композитные панели симметричные или квази изотропные в целом.
\end{abstract}

Ключевые слова: композитные материалы, сотовая структура, сэндвич-панель, панель, изгибание, скручивание, модуль упругости при изгибе, метод конечных элементов. 


\title{
Module de cisaillement effectif des panneaux composites en nid d'abeilles
}

\begin{abstract}
Dans ce papier on a déterminé le module effectif de cisaillement des panneaux composites en nid d'abeilles. Ce coefficient élastique est une caractéristique importante des panneaux composites particulièrement chez les constructions composites exposées aux torsions et aux combinaisons flexion - torsion. Les structures analysées dans ce travail se composent de deux plaques composites- supérieure et inférieure - de différents types de fibres de carbone (T 300, AS4 dans une matrice époxy) ainsi que d'un noyau en nid d'abeilles(Hex Web engineered score). Partant de la théorie classique de lamine le module effectif de cisaillement des deux plaques a été déterminé pour chaque couche. Ces couches sont ressemblées en une seule couche pour les différentes orientations des fibres et pour les différents épaisseurs de lamine. Les coefficients élastiques pour le HexWeb noyau du panneau composite ont été calculés à l'aide de la théorie Master Evans afin d'obtenir les valeurs équivalentes. Pour la vérification de l'approche proposée on a utilisé la méthode des éléments finis dans le but de déterminer le champ de déplacement, des déformations et de tension dans les plaques composites et dans le noyau en nid d'abeilles. Deux types de modèles numériques ont été comparés : modèle initial ou toutes les couches de la plaque ont été modélisées selon leurs caractéristiques et le modèle rassemblé avec ses caractéristiques équivalentes On a conclu que le modèle équivalent de la détermination du module de cisaillement des matériaux composites au noyau en nid d'abeilles pouvait s'appliquer efficacement dans les cas où les plaques supérieure et inférieure sont symétriques ou quasi isotropes généralement.
\end{abstract}

Mots clés: matériaux composites, structure en nid d'abeilles, panneau, plaque, torsion, flexion, module de cisaillement, méthode des éléments finis. 